\title{
PENGARUH MOTIVASI, KOMPENSASI DAN LINGKUNGAN KERJA KARYAWAN TERHADAP KINERJA KARYAWAN DI KANTOR DINAS SOSIAL TENAGA KERJA DAN TRANSMIGRASI KOTA YOGYAKARTA
}

\author{
Badriyah \\ pupakmelak@gmail.com \\ Universitas Ahmad Dahlan \\ Ani Muttaqiyathun \\ animtq@gmail.com \\ Universitas Ahmad Dahlan
}

\begin{abstract}
ABSTRAK
This research aims to understand how the influence of motivation, compensation and workplace on the performance of employees at department office social man power and transmigration the city of Yogyakarta bot a partial as well as simultaneous or together. The population on this research is Employees who worked at social department office of manpower and transmigration city of Yogyakarta. The sample collection technique in this research use of sampling methods purposive. The total sample taken in this research as many 81 respondents. The source of data from the study used data primary obtained from the results of questionnaires compiled using likert scale. This study using data analysis techniques is the quantitative analysis (linear regression analysis double, $t$ test and test $f$ ). Test results $t$ show that the significance of the variables ( $x 1$ ) 0,007 value $<\alpha=0.05$, then motivation influential significantly to employee performance, then motivation influential significantly to employee performance, variable compensation ( x2 ) $0,038<$ value $\alpha=0.05$ then compensation significant of the performance of employees and variable workplace (x3) $0,048<$ value $\alpha=0.05$ and a significant effect on the employees in social department office of manpower and transmigration the city of Yogyakarta.
\end{abstract}

Keywords: Motivation, Compensation, Workplace, Performance of Employee.

\section{PENDAHULUAN}

Peningkatan pengelolaan Sumber Daya Manusia harus dilakukan untuk membantu perekonomian Negara dengan mengurangi angka pengangguran. Upaya yang dapat dilakukan adalah menyediakan lapangan pekerjaan. Salah satunya dengan cara mendirikan suatu perusahaan agar Sumber Daya Manusia (tenaga kerja) yang ada menjadi produktif.

Pengelolaan Sumber Daya Manusia yang efektif, yaitu meningkatkan kualitas Sumber Daya Manusia (tenaga kerja) dengan menghubungkan individu dengan pekerjaan harus diperhatikan di setiap organisasi. Sumber Daya Manusia sebagai tenaga kerja sangat mempengaruhi berhasil atau tidaknya suatu organisasi dalam pencapian tujuan, Sumber Daya Manusia yang ada menjadi salah satu faktor penting dalam dunia kerja, memiliki peran utama dalam perencanaan sampai dengan evaluasi dan mampu memanfaatkan sumber daya lainnya yang dimiliki oleh organisasi.

Sumber Daya Manusia yang memiliki kinerja yang baik dibutuhkan oleh setiap organisasi. Peningkatan kinerja, kualitas kinerja karyawan dalam hal ini harus diperhatikan, karena akan berpengaruh terhadap apa yang dihasilkan karyawan untuk organisasi. 
Pemberian kompensasi dilakukan oleh organisasi kepada karyawan sebagai balas jasa atas apa yang telah diberikan karyawan untuk organisasi dengan tujuan kebutuhankaryawan dapat terpenuhi. Dalam hal ini, selain motivasi, kompensasi lingkungan kerja yang baik aman dan nyaman juga menjadi hal yang penting bagi setiap organisasi. Beberapa hal yang telah disebutkan di atas akan mendorong karyawan untuk lebih berperestasi dan produktif.

Tujuan dari penelitian ini di antaranya: 1) untuk menguji apakah terdapat pengaruh motivasi terhadap kinerja karyawan di Kantor Dinas Sosial Tenaga Kerja dan Transmigrasi Kota Yogyakarta, 2) untuk menguji apakah terdapat pengaruh kompensasi terhadap kinerja karyawan di Kantor Dinas Sosial Tenaga Kerja dan Transmigrasi Kota Yogyakarta, 3) untuk menguji apakah terdapat pengaruh lingkungan kerja karyawan terhadap kinerja karyawan di Kantor Dinas Sosial Tenaga Kerja dan Transmigrasi Kota Yogyakarta, 4) untuk menguji apakah terdapat pengaruh motivasi, kompensasi dan lingkungan kerja karyawan terhadap kinerja karyawan secara bersama-sama di Kantor Dinas Sosial Tenaga Kerja dan Transmigrasi Kota Yogyakarta.

\section{REVIEW LITERATUR DAN HIPOTESIS}

\section{Landasan Teori}

1. Motivasi

Motivasi adalah suatu proses dimana kebutuhan-kebutuhan mendorong seseorang untuk melakukan serangkaian kegiatan yang mengarah ketercapainya tujuan tertentu (Munandar, 2001).

2. Kompensasi

Kompensasi adalah semua bentuk pembayaran yang diberikan kepada pegawai dalam bentuk pembayaran langsung (dalam bentuk uang) atau tidak langsung (dalam bentuk tunjangan insentif). Sebagai salah satu bagian penting dari manjemen sumber daya manusia, manajemen kompensasi sangat mempengaruhi kompetensi perusahaan (Riani, 2011).

3. Lingkungan Kerja

Menurut Nitisemito (2000) mendefinisikan bahwan lingkungan kerja adalah segala sesuatu yang ada disekitar para pekerja yang dapat mempengaruhi dirinya dalam menjalankan tugas-tugas yang dibebankan.

4. Kinerja Karyawan

Menurut Simamora kinerja adalah tingkat terhadapnya para karyawan mencapai persyaratanpersyaratan pekerjaan.

\section{Penelitian Terdahulu}

1. Sulistyo Cahyo Hadi Saputro (2012) melakukan penelitian dengan judul Pengaruh Motivasi dan Lingkungan Kerja Terhadap Kinerja Karyawan di Puskesmas Prambanan. Penelitian ini menyimpulkan bahwa :

a. Motivasi berpengaruh positif dan signifikan terhadap kinerja karyawan secara parsial di Puskesms Prambanan.

b. Lingkungan Kerja berepengaruh positif dan tidak signifikan terhadap kinerja karyawan secara parsial di Puskesmas Prambanan.

c. Motivasi dan Lingkungan Kerja secara bersama-sama berpengaruh yang signifikan terhadap kinerja karyawan di Puskesmas Prambanan.

2. Mohamad Yusi Eko Saputro (2011) melakukan penelitian dengan judul Pengaruh Pemberian Kompensasi dan Lingkungan Kerja terhadap Kinerja Karyawan di PDAM Tirtamarta Yogyakarta, penelitian ini menyimpulkan bahwa: 
a. Pemberian kompensasi berpengaruh positif dan signifikan terhadap kinerja karyawan secara parsial di PDAM Tirtamarta Yogyakarta.

b. Lingkungan Kerja Berpengaruh positif dan signifikan terhadap kinerja karyawan secara parsial di PDAM Tirtamarta Yogyakarta.

c. Pemberian kompensasi dan lingkungan kerja bepengaruh signifikan terhadap kinerja karyawan secara simultan di PDAM Tirtamarta Yogyakarta.

\section{Hipotesis}

H1: Diduga terdapat pengaruh motivasi terhadap kinerja karyawan di Kantor Dinas Sosial Tenaga Kerja dan Transmigrasi Kota Yogyakarta.

H2: Diduga terdapat pengaruh kompensasi terhadap kinerja karyawan di Kantor Dinas Sosial Tenaga Kerja dan Transmigrasi Kota Yogyakarta.

H3: Diduga terdapat pengaruh lingkungan kerja karyawan terhadap kinerja karyawan di Kantor Dinas Sosial Tenaga Kerja dan Transmigrasi Kota Yogyakarta.

H4: Diduga terdapat pengaruh motivasi, kompensasi, dan lingkungan kerja karyawan terhadap kinerja karyawan secara bersama-sama di Kantor Dinas Sosial Tenaga Kerja dan Transmigrasi Kota Yogyakarta.

\section{METODE PENELITIAN}

\section{Populasi dan Sampel}

Populasi adalah wilayah generalisasi yang terdiri atas obyek/subyek yang mempunyai kualitas dan karakteristik tertentu yang ditetapkan oleh peneliti untuk dipelajari dan kemudian ditarik kesimpulannya (Sugiyono, 2008). Populasi pada penelitian ini berjumlah 90 karyawan yaitu karyawan di Kantor Dinas
Sosial Tenaga Kerja dan Transmigrasi Kota Yogyakarta.

Sampel adalah bagian dari jumlah dan karakteristik yang dimiliki oleh populasi tersebut. Bila populasi besar, dan peneliti tidak mungkin mempelajari semua yang ada pada populasi, misalnya karena keterbatasan dana, tenaga dan waktu, maka peneliti dapat menggunakan sampel yang diambil dari populasi itu. (Sugiyono, 2009). Sampel yang digunakan pada penelitian ini sebanyak 90 karyawan. Kuesioner yang disebarkan sebanyak 90 dan yang kembali 81 kuesioner sisanya rusak/tidak kembali.

\section{Definisi Operasional}

1. Variabel Independen

a. Motivasi

Motivasi adalah suatu proses dimana kebutuhan-kebutuhan mendorong seseorang untuk melakukan serangkaian kegiatan yang mengarah ketercapainya tujuan tertentu (Munandar, 2001).

b. Kompensasi

Kompensasi adalah semua bentuk pembayaran yang diberikan kepada pegawai dalam bentuk pembayaran langsung (dalam bentuk uang) atau tidak langsung (dalam bentuk tunjangan insentif). Sebagai salah satu bagian penting dari manjemen sumber daya manusia, manajemen kompensasi sangat mempengaruhi kompetensi perusahaan (Riani, 2011).

c. Lingkungan Kerja

Menurut Nitisemito (2000) mendefinisikan bahwan lingkungan kerja adalah segala sesuatu yang ada disekitar para pekerja yang dapat mempengaruhi dirinya dalam menjalankan tugas-tugas yang dibebankan. 
2. Variabel Dependen

Variabel dependen (Y) yang digunakan dalam penelitian ini adalah kinerja karyawan. Menurut Simamora (1999) kinerja adalah tingkat terhadapnya para karyawan mencapai persyaratan-persyaratan pekerjaan.

\section{Uji Instrumen}

\section{Uji Validitas}

Validitas adalah instrumen yang dapat digunakan untuk mengukur apa yang seharusnya dapat diukur (Sugiyono, 2009). Validitas digunakan untuk mengetahui kesamaan antara data yang terkumpul dengan data yang sesungguhnya terjadi pada objek yang di teliti, sehingga terdapat data yang valid.

Tipe validitas adalah validitas konstruk (Construc Validity) menentukan validitas alat pengukur dengan mengkorelasikan antara skor yang diperoleh masing-masing item yang berupa pernyataan atau pertanyaan dengan skor totalnya, skor total ini merupakan nilai yang diperoleh dari hasil penjumlahan semua skor item, korelasi antar skor item dengan skor totalnya harus signifikan berdasarkan ukuran statistik tertentu. Bila semua item yang disusun berdasarkan dimensi konsep berkolerasi dengan skor totalnya, maka dapat disimpulkan bahwa alat pengukur tersebut mempunyai validitas. Bila korelasi tiap faktor tersebut positif dan besarnya $0,3 \mathrm{ke}$ atas maka faktor tersebut merupakan Construct yang kuat. Jadi berdasarkan analisis faktor itu dapat disimpulkan bahwa instrumen tersebut memiliki validitas kontruksi yang baik (Sugiyono, 2009).

\section{Uji Reliabilitas}

$$
\text { Uji ini dilakukan untuk }
$$
mengetahui tingkat konsistensi hasil pengukuran bila dilakukan pengukuran data dua kali atau lebih gejala yang sama. Hasilnya ditunjukkan oleh sebuah indeks yang menunjukkan seberapa jauh suatu alat ukur dapat dipercaya. Uji ini diterapkan untuk mengetahui apakah responden telah menjawab pertanyaan-pertanyaan secara konsisten atau tidak, sihingga kesungguhan jawabannya dapat dipercaya. Untuk melihat reliabilitas instrumen akan di hitung Alpha Cronbach masing-masing instrumen. Menurut Arikunto (1995) variabel dikatakan reliabel jika memiliki nilai Alpha Cronbach $\geq 0,60$.

\section{Teknik Analisis Data}

1. Analisis Regresi Berganda

Analisis data regresi linier berganda, merupakan analisis data yang menghubungkan dua variabel atau lebih untuk mengetahui besarnya pengaruh dari perubahan variabel bebas terhadap variabel terikat dan dengan bantuan program SPSS 20. Dengan menggunakan analisi regresi linier berganda dapat diketahui pengaruh variabel independen motivasi (X1), kompensasi (X2), lingkungan kerja karyawan (X3) terhadap variabel dependen kinerja karyawan (Y). Pengaruh antara variabel dependen diformulasikan dalam persamaan regresi sebagai berikut:

$\mathrm{Y}=\alpha+\beta 1 \mathrm{X} 1+\beta 2 \mathrm{X} 2+\beta 3 \mathrm{X} 3$

Keterangan:

$\mathrm{Y}=$ Kinerja Karyawan

$\mathrm{A}=$ Nilai Konstanta

$\beta=$ Koefisien Variabel

$\mathrm{X} 1$ = Motivasi

$\mathrm{X} 2$ = Kompensasi

X3 = Lingkungan Kerja 


\section{Uji Hipotesis}

1. Uji Parsial (Uji T)

Uji $\mathrm{T}$ digunakan untuk mengetahui signifikansi pengaruh variabel independen secara individu terhadap variabel dependen untuk menyatakan menolak atau menerima hipotesis.

Jika $\mathrm{t}$ hitung $>\mathrm{t}$ tabel maka, HO ditolak dan Ha diterima.

Jika $\mathrm{t}$ hitung $<\mathrm{t}$ tabel maka, H0 diterima dan Ha ditolak.

Jika probabilitas > 0,05, H0 diterima maka (tidak ada pengaruh)

Jika probabilitas < 0,05, H0 ditolak maka (ada pengaruh)

\section{Uji Simultan (Uji F)}

Uji $F$ ini digunakan untuk menghitung signifikansi pengaruh variabel independen secara bersamasama terhadap variabel dependen.

Jika $\mathrm{F}$ hitung > F tabel maka, H0 ditolak dan Ha diterima.

Jika $\mathrm{F}$ hitung < F tabel maka, H0 diterima dan Ha ditolak.

Jika probabilitas > 0,05, H0 diterima maka (tidak ada pengaruh)

Jika probabilitas < 0,05, H0 ditolak maka (ada pengaruh)

\section{HASIL PENELITIAN DAN PEMBAHASAN}

\section{Hasil Analisis Responden}

\begin{tabular}{|c|c|c|}
\hline \multicolumn{3}{|c|}{ Data Jenis Kelamin Responden } \\
\hline Jenis Kelamin & Jumlah & Persentase (\%) \\
\hline Laki-laki & 34 & $41,98 \%$ \\
\hline Perempuan & 47 & $58,02 \%$ \\
\hline Jumlah & 81 & $100 \%$ \\
\hline
\end{tabular}

Berdasarkan tabel di atas dapat diketahui bahwa dari jumlah 81 responden dilihat dari karakteristik responden berdasar jenis kelamin sebanyak 34 orang $(41,98 \%)$ berjenis kelamin laki-laki dan 37 $(58,02 \%)$ orang berjenis kelamin perempuan.

\begin{tabular}{|l|c|c|}
\multicolumn{3}{|c}{ Data Usia Responden } \\
\hline \multicolumn{1}{|c|}{ Usia } & Jumlah & Persentase (\%) \\
\hline$<25$ Tahun & 5 orang & $6,18 \%$ \\
\hline $25-40$ Tahun & 36 orang & $44,44 \%$ \\
\hline$>40$ Tahun & 40 orang & $49,38 \%$ \\
\hline Jumlah & 81 orang & $100 \%$ \\
\hline
\end{tabular}

Berdasarkan tabel di atas dapat diketahui bahwa dari jumlah 81 responden dilihat dari karakteristik responden berdasarkan usia sebanyak 5 orang $(6,18 \%)$ berusia $<25$ tahun, 26 orang $(44,4 \%)$ berusia $25-40$ tahun dan 30 $(49,38 \%)$ berusia $>41$ tahun.

\begin{tabular}{|l|c|c|}
\hline \multicolumn{2}{|c|}{ Dabatan Jabatan Responden } \\
\hline Staf & Jumlah & Persentase (\%) \\
\hline $\begin{array}{l}\text { Pengawas Ketenagakerjaan } \\
\text { Pertama }\end{array}$ & 39 Orang & $48 \%$ \\
\hline Ka. Sub.Bag.Umum Kepegawaian & 2 Orang & $6,2 \%$ \\
\hline Kepegawaian & 1 Orang & $1,2 \%$ \\
\hline Ka.Sie & 1 Orang & $1,2 \%$ \\
\hline Tenaga Teknis RPS & 1 Orang & $1,2 \%$ \\
\hline Sub.Bag.Keungan & 5 Orang & $6,2 \%$ \\
\hline UPT Panti Weda Budhi Darma & 10 Orang & $12,3 \%$ \\
\hline Sekretariat & 1 Orang & $1,2 \%$ \\
\hline Pengurus Barang & 2 Orang & $2,5 \%$ \\
\hline Peksos & 3 Orang & $3,7 \%$ \\
\hline $\begin{array}{l}\text { Pengemudi Bagian Umum } \\
\text { Kepegawaian }\end{array}$ & 1 Orang & $1,2 \%$ \\
\hline Sub.Bag.ADP & 1 Orang & $1,2 \%$ \\
\hline $\begin{array}{l}\text { Bidang Pengembangan Tenaga } \\
\text { Kerja }\end{array}$ & 9 Orang & $11,1 \%$ \\
\hline Jumlah & 81 Orang & $100 \%$ \\
\hline
\end{tabular}

Data dari tabel di atas dapat diketahui bahwa dari jumlah 81 responden dilihat dari karakteristik responden berdasarkan jabatan yaitu terdiri dari , Staf $=39$ orang $(48 \%), \quad$ Pengawas Ketenagakerjaan Pertama $=5$ orang $(6,2 \%)$, Ka. Sub. Bagian Umum Kepagawaian $=2$ orang $(2,5 \%)$, Kepegawaian $=1$ orang $(1,2 \%), \mathrm{Ka} . \mathrm{Sie}=$ 1 orang $(1,2 \%)$, Tenaga Teknis RPS $=1$ orang $(1,2 \%)$, Sub. Bag. Keuangan $=5$ orang (6,2\%), UPT Panti Weda Budhi Dharma $=10$ orang $(12,3 \%)$, Sekretariat $=1$ orang $(1,2 \%)$, Pengurus Barang $=2$ orang $(2,5 \%)$, Peksos $=3$ orang $(3,7 \%)$, Penegemudi Bagian Umum Kepegawaian $=1$ orang $(1,2 \%)$, Sub. Bag. Umum ADP $=1$ orang $(1,2 \%)$ dan Bidang 
Pengembangan Tenaga Kerja $=9$ orang $(11,1 \%)$.

\begin{tabular}{|l|c|c|}
\multicolumn{1}{c}{} & Data Usia Kerja Responden \\
\hline \multicolumn{1}{|c|}{ Usia Kerja } & Jumlah & Persentase (\%) \\
\hline$<1$ Tahun & 8 Orang & $9,9 \%$ \\
\hline $1-10$ Tahun & 25 Orang & $30,9 \%$ \\
\hline$>10$ Tahun & 48 Orang & $59,2 \%$ \\
\hline Jumlah & 81 Orang & $100 \%$ \\
\hline
\end{tabular}

Dari tabel di atas dapat diketahui bahwa dari jumlah 81 responden dilihat dari karekteristik responden berdasar usia kerja sebanyak 8 orang $(9,9 \%)<1$ tahun, 25 orang (30,9\%) 1-10 tahun dan 48 orang $(59,2 \%)>10$ Tahun.

\section{Hasil Penelitian}

1. Hasil Uji Validitas

a. Variabel Motivasi (X1)

Variabel Motivasi (X1)

\begin{tabular}{|c|l|c|c|}
\hline \multirow{2}{*}{ No } & \multicolumn{3}{|c|}{ Indikator Kebutuhan Akan } \\
\cline { 2 - 4 } & r hitung & r tabel & Ket \\
\hline 1 & $0,685^{* *}$ & 0.361 & Valid \\
\hline 2 & $0,691^{* *}$ & 0.361 & Valid \\
\hline 3 & $0,726^{* *}$ & 0.361 & Valid \\
\hline 4 & $0,498^{* *}$ & 0.361 & Valid \\
\hline 5 & $0,647^{* *}$ & 0.361 & Valid \\
\hline \multirow{3}{*}{ No } & \multicolumn{3}{|c|}{ Indikator Kebutuhan Akan } \\
\cline { 2 - 4 } & r hitung & r tabel & Ket \\
\hline 1 & $0,681^{* *}$ & 0.361 & Valid \\
\hline 2 & $0,479^{* *}$ & 0.361 & Valid \\
\hline 3 & $0,869^{* *}$ & 0.361 & Valid \\
\hline 4 & $0,779^{* *}$ & 0.361 & Valid \\
\hline \multirow{3}{*}{ No } & \multicolumn{3}{|c|}{ Indikator Kebutuhan Akan } \\
\cline { 2 - 4 } & \multicolumn{3}{|c|}{ Afiliasi } \\
\hline 1 & $0,823^{* *}$ & 0.361 & Valid \\
\hline 2 & $0,747^{* *}$ & 0.361 & Valid \\
\hline 3 & $0,723^{* *}$ & 0.361 & Valid \\
\hline
\end{tabular}

b. Variabel Kompensasi (X2) Variabel Kompensasi (X2)

\begin{tabular}{|c|l|c|c|}
\hline \multirow{2}{*}{ No } & \multicolumn{3}{|c|}{ Variabel Kompensasi } \\
\cline { 2 - 4 } & r hitung & r tabel & Ket \\
\hline 1 & $0,493^{* *}$ & 0.361 & Valid \\
\hline 2 & $0,560^{* *}$ & 0.361 & Valid \\
\hline 3 & $0,795^{* *}$ & 0.361 & Valid \\
\hline 4 & $0,911^{* *}$ & 0.361 & Valid \\
\hline 5 & $0,867^{* *}$ & 0.361 & Valid \\
\hline 6 & $0,762^{* *}$ & 0.361 & Valid \\
\hline
\end{tabular}

c. Variabel Lingkungan Kerja (X3) Variabel Lingkungan kerja

\begin{tabular}{|c|c|c|c|}
\hline \multirow{2}{*}{ No } & \multicolumn{3}{|c|}{ Indikator Pewarnaan } \\
\cline { 2 - 4 } & r hitung & r tabel & Ket \\
\hline 1 & $0,908^{* *}$ & 0.361 & Valid \\
\hline 2 & $0,785^{* *}$ & 0.361 & Valid \\
\hline \multirow{3}{*}{ No } & \multicolumn{3}{|c|}{ Indikator Kebersihan } \\
\cline { 2 - 4 } & r hitung & r tabel & Ket \\
\hline 1 & $0,924^{* *}$ & 0.361 & Valid \\
\hline 2 & $0,858^{* *}$ & 0.361 & Valid \\
\hline 3 & $0,783^{* *}$ & 0.361 & Valid \\
\hline \multirow{3}{*}{ No } & \multicolumn{3}{|c|}{ Indikator Pengaturan } \\
\cline { 2 - 4 } Udara/Ventilasi \\
\cline { 2 - 4 } & r hitung & r tabel & Ket \\
\hline 1 & $0,903^{* *}$ & 0.361 & Valid \\
\hline 2 & $0,867^{* *}$ & 0.361 & Valid \\
\hline 3 & $0,523^{* *}$ & 0.361 & Valid \\
\hline \multirow{3}{*}{ No } & \multicolumn{3}{|c|}{ Indikator Penerangan } \\
\cline { 2 - 4 } & r hitung & r tabel & Ket \\
\hline 1 & $0,692^{* *}$ & 0.361 & Valid \\
\hline 2 & $0,919^{* *}$ & 0.361 & Valid \\
\hline 3 & $0,496^{* *}$ & 0.361 & Valid \\
\hline \multirow{3}{*}{ No } & \multicolumn{3}{|c|}{ Indikator Keamanan } \\
\cline { 2 - 4 } & r hitung & r tabel & Ket \\
\hline 1 & $0,755^{* *}$ & 0.361 & Valid \\
\hline 2 & $0,642^{* *}$ & 0.361 & Valid \\
\hline 3 & $0,536^{* *}$ & 0.361 & Valid \\
\hline \multirow{2}{*}{ No } & \multicolumn{3}{|c|}{ Indikator Kebisingan } \\
\cline { 2 - 4 } & r hitung & r tabel & Ket \\
\hline 1 & $0,842^{* *}$ & 0.361 & Valid \\
\hline 2 & $0,930^{* *}$ & 0.361 & Valid \\
\hline & \multicolumn{3}{|c}{} \\
\hline
\end{tabular}


d. Variabel Kinerja Karyawan (Y)

Variabel Kinerja

\begin{tabular}{|c|c|c|c|}
\hline \multirow{2}{*}{ No } & \multicolumn{3}{|c|}{ Variabel Kinerja } \\
\cline { 2 - 4 } & r hitung & r tabel & Ket \\
\hline 1 & $0,481^{* *}$ & 0.361 & Valid \\
\hline 2 & $0,685^{* *}$ & 0.361 & Valid \\
\hline
\end{tabular}

\begin{tabular}{|l|l|l|l|}
\hline 3 & $0,819^{* *}$ & 0.361 & Valid \\
\hline 4 & $0,557^{* *}$ & 0.361 & Valid \\
\hline 5 & $0,637^{* *}$ & 0.361 & Valid \\
\hline 6 & $0,590^{* *}$ & 0.361 & Valid \\
\hline 7 & $0,857^{* *}$ & 0,361 & Valid \\
\hline 8 & $0,609^{* *}$ & 0,361 & Valid \\
\hline
\end{tabular}

2. Hasil Uji Reliabilitas

\begin{tabular}{|l|c|c|c|}
\multicolumn{1}{|c}{ Rangkuman Hasil Uji Reliabilitas Instrumen Pertanyaan } \\
\hline Variabel & Cronbach Alpha & $\begin{array}{c}\text { Alpha } \\
\text { (Konstruk) }\end{array}$ & Keputusan \\
\hline Motivasi & 0,617 & 0,60 & Reliabel \\
\hline Kompensasi & 0,841 & 0,60 & Reliabel \\
\hline Lingkungan Kerja & 0,785 & 0,60 & Reliabel \\
\hline Kinerja Karyawan & 0,801 & 0,60 & Reliabel \\
\hline
\end{tabular}

Berdasarkan ringkasan hasil uji kehandalan (reliabilitas) di atas, maka dpat diketahui nilai koefisien Cronbach Alpha pada masing-masing variabel nilainya $>0,60$, sehingga dapat disimpulkan bahwa semua butir pertanyaan dalam penelitian ini dalah handal dan dapat digunakan untuk penelitin selanjutnya.

3. Hasil Uji Regresi Linier Berganda Hasil Analisis Regresi Berganda

\begin{tabular}{|c|c|c|c|}
\hline Variabel & $\begin{array}{c}\text { Koefisisen } \\
\text { Regresi }\end{array}$ & t hitung & Sig \\
\hline $\mathrm{X} 1$ & 0,279 & 2,755 & 0,007 \\
\hline $\mathrm{X} 2$ & 0,225 & 2,108 & 0,038 \\
\hline $\mathrm{X} 3$ & 0,214 & 2,011 & 0,048 \\
\hline Konstan & 1,021 & 1,434 & 0,156 \\
\hline \multicolumn{4}{|c|}{$\begin{array}{r}\text { F hitung }=6,997 \\
\text { Sign }=0,000\end{array}$} \\
\hline
\end{tabular}

Dari tabel di atas, maka hasil yang diperoleh dimasukan kedalam persamaan regresi sebagai berikut:

$\mathrm{Y}=\mathrm{a}+\mathrm{b} 1 \mathrm{X} 1+\mathrm{b} 2 \mathrm{X} 2+\mathrm{b} 3 \mathrm{X} 3$

$\mathrm{Y}=1,021+0,279 \mathrm{x} 1+0,225 \mathrm{x} 2+0,214 \times 3$

$\mathrm{a}=1,021$, artinya jika tidak ada perubahan pada motivasi, kompensasi dan lingkungan kerja (variabel bebas), maka nilai kinerja karyawan sebesar 1,021 sebagai nilai konstan untuk variabel terikat.

$\mathrm{b} 1=0,279$, artinya setiap penambahan motivasi mempengaruhi peningkatan kinerja karyawan sebesar 0,279. Koefisien bernilai positif, artinya terjadi hubungan positif antara motivasi dengan kinerja karyawan, semakin bertambah motivasi maka akan berepengaruh pada peningkatan kinerja karyawan.

b2 $=0,225$, artinya setiap penambahan kompensasi akan mempengaruhi peningkatan kinerja karyawan sebesar 0,225 . Koefisien bernilai positif artinya terjadi hubungan positif antara kompensasi dengan kinerja karyawan, semakin baik kompensasi yang diberikan kepada karyawan maka semakin meningkat kinerja karyawan.

b3 $=0,214$, artinya setiap penambahan lingkungan kerja akan mempengaruhi peningkatan kinerja karyawan sebesar 0,214. Koefisien bernilai positif artinya terjadi hubungan positif antara lingkungan kerja dengan kinerja karyawan, semakin baik lingkungan kinerja yang diberikan kepada karyawan maka semakin meningkat kinerja karyawan

\section{Hasil Uji Parsial (Uji T)}

a. Pengaruh Motivasi Terhadap Kinerja Karyawan.

Hasil olah data menunjukkan bahwa adanya pengaruh signifikan antara motivasi terhadap kinerja karyawan. Ditunjukkan dengan probabibilitas $0,007<0,05, \mathrm{H} 0$ ditolak maka (ada pengaruh) dan nilai $t$ hit $>\mathrm{t}$ tabel $(2,755>1,990)$. Maka HO ditolak dan Ha diterima, artinya motivasi berpengaruh signifikan terhadap kinerja.

b. Pengaruh Kompensasi Terhadap Kinerja Karyawan.

Hasil olah data menunjukkan bahwa adanya pengaruh signifikan 
antara kompensasi terhadap kinerja. Ditunjukkan dengan nilai t hitung $>\mathrm{t}$ tabel $(2,108>1,990)$. Maka Ho ditolak dan $\mathrm{Ha}$ diterima Probabilitas $0,038<0,05$, H0 maka ditolak.

c. Pengaruh Lingkungan Kerja Terhadap Kinerja Karyawan.

Hasil olah data menunjukkan bahwa terdapat pengaruh signifikan antara kompensasi terhadap kinerja. Ditunjukkan dengan nilai t hitung > t tabel $(2,011<1,990)$. Maka, maka Ho diterima, dan $\mathrm{Ha}$ ditolak dan probabilitas $0,048<0,05$ maka $\mathrm{H} 0$ maka dotolak (ada pengaruh) artinya kompensasi tidak berpengaruh signifikan terhadap kinerja karyawan.

5. Hasil Uji Simultan (Uji F) Hasil Analisis Uji F

\begin{tabular}{|c|c|}
\hline F & Sig \\
\hline 6,997 & 0,000 \\
& \\
& \\
\hline
\end{tabular}

Hasil uji simultan menunjukkan bahwa adanya pengaruh signifikan antara variabel motivasi, kompensasi dan variabel lingkungan kerja terhadap kinerja secara bersama-sama. Ditunjukkan dengan nilai $\mathrm{F}$ hitung > F tabel $(6,997>2,72$. Maka Ho ditolak dan $\mathrm{Ha}$ diterima artinya terdapat pengaruh signifikan antara variabel motivasi, kompensasi dan lingkungan kerja terhadap kinerja karyawan secara simultan.

\section{Pembahasan}

Berdasarkan teori dan alat analisis data yang digunakan dalam penelitian ini adalah regresi linier berganda, $\mathrm{Uji} t$ dan Uji $F$ yang telah diuraikan sebelumnya, menunjukan bahwa variabel motivasi, kompensasi dan lingkungan kerja berepengaruh signifikan secara parsial dan simultan terhadap kinerja.
Ditunjukan dengan nilai t hitung $>\mathrm{t}$ tabel dan F hitung $>$ F tabel. Selanjutnya variabel motivasi, kompensasi dan lingkungan kerja berdasarkan hasil analisis linear berganda variabel motivasi, kompensasi dan lingkungan kerja berpengaruh signifikan terhadap kinerja karena memiliki nilai koefesien bertanda positif. Maka hipotesis dalam penelitian ini, berdasarkan teori dan alat analisis data Uji $t$ dan Uji $F$ untuk variabel motivasi, kompensasi dan lingkungan kerja terhadap kinerja karyawan berpengaruh secara parsial dan simultan.

Data yang dikumpulkan berhasil membuktikan hipotesis dan berhasil membuktikan keterkaitan antara variabel $\mathrm{X}$ dan $\mathrm{Y}$ secara parsial maupun simultan, yaitu variabel motivasi, kompensasi, dan lingkungna kerja karyawan berpengaruh signifikan teradap kinerja karyawan secara parsial dan simultan di Kantor Dinas Sosial Tenaga Kerja Dan Transmigrasi Kota Yogyakarta.

\section{KESIMPULAN DAN SARAN}

\section{Kesimpulan}

1. Berdasarkan hasil analisis Uji $T$ menunjukkan bahwa variabel motivasi berpengaruh signifikan terhadap kinerja. Ditunjukkan dengan nilai $\mathrm{T}$ hitung > t tabel $(2,755>1,990)$ dan probabilitas $0,007<0,05$, maka $\mathrm{H} 0$ ditolak dan $\mathrm{Ha}$ diterima artinya terdapat pengaruh signifikan antara motivasi terhadap kinerja karyawan secara parsial.

2. Berdasarkan hasil analisis Uji $T$ menunjukkan bahwa variabel kompensasi berpengaruh signifikan terhadap kinerja. Ditunjukkan dengan nilai $\mathrm{t}$ hitung $<\mathrm{t}$ tabel $(2,108>1,990)$ dan probabilitas $0,038>0,05$, maka $\mathrm{H} 0$ ditolak dan $\mathrm{Ha}$ diterima artinya terdapat pengaruh signifikan antara motivasi terhadap kinerja karyawan secara parsial. 
3. Berdasarkan hasil analisis Uji $\mathrm{T}$ menunjukkan bahwa variabel lingkungan kerja berpengaruh signifikan terhadap kinerja. Ditunjukkan dengan nilai $\mathrm{t}$ hitung $>\mathrm{t}$ tabel $(2,011>1,990)$ probabiltas 0,048 $>0,05$ maka $\mathrm{H0}$ ditolak dan $\mathrm{Ha}$ diterima artinya terdapat pengaruh signifikan antara lingkungan kerja terhadap kinerja karyawan secara parsial.

4. Berdasarkan hasil analisis Uji F menunjukkan bahwa terdapat pengaruh signifikan antara variabel motivasi, kompensasi dan lingkungan kerja terhadap kinerja karyawan. Ditunjukkan dengannilai $\mathrm{F}$ hitung > F tabel $(6,997>2,72)$ dan probabilitas 6,997 > 0,000. Maka H0 ditolak, dan Ha diterima artinya berpengaruh signifikan antara variabel motivasi, kompensasi dan lingkungan kerja terhadap kinerja karyawan secara simultan di Kantor Dinas Sosial Tenaga Kerja Dan Transmigrasi Kota Yogykarta.

\section{Saran}

1. Bagi Kantor Dinas Sosial Tenaga Kerja dan Transmigrasi Kota Yogyakarta

Berdasarkan hasil analisis dan kesimpulan yang berkaitan dengan penelitian ini, maka saran-saran yang dapat diajukan sebagai masukan di Kantor Dinas Sosial Tenaga Kerja dan Transmigrasi Kota Yogyakarta adalah kinerja karyawan dapat ditingktkan dengan melakukan pemberian motivasi yaitu dapat dilakukan dengan berinteraksi dan berkomunikasi dengan karyawan, menjalin kerjasama yang baik ditempat kerja, pemberian kompensasi salah satunya dapat dilakukan dengan caramemberikan pelayanan kesehatan kepada karyawan dengan kata lain karyawan mendapatkan asuransi ditempat bekerja, selain hal yang telah disebutkan di atas, lingkungan kerja merupakan hal pokok yang harus diperhatikan demi keamanan dan kenyamanan karyawan dalam bekerja di organisasi, menciptakan suasana kerja yang baik dan kondusif dapat dilakukan dengan menjaga kebersihan lingkungan, memperhatikan pewarnaan ruangan tempat bekerja, pengaturan udara/ventilasi, penerangan, kebisingan serta selalu menjaga keamanan tempat bekerja.

2. Bagi Peneliti Selanjutnya

Hendaknya melakukan penelitian dengan menggunakan faktorfaktor motivasi selain kebutuhan akan prestasi, kebutuhan akan kekuasaan, kebutuhan akan afiliasi dalam upaya peningkatan kinerja karyawan.

\section{DAFTAR PUSTAKA}

Arikunto, Suharsimi. (1995). Manajemen Penelitian. Jakarta: Rineka Cipta.

Munandar, Ashar Sunyoto. (2001). Psikologi Industri dan Organisasi. Universitas Indonesia Jakarta.

Nitisemito, Alex S. (2000). Manajemen Personalia: Manajemen Sumber Daya Manusia. Edisi Ketiga. Jakarta: Ghalia Indonesia.

Riani. (2013). Manajemen Sumber Daya Manusia Masa Kini. Yogyakarta: Graha Ilmu.

Simamora, Henry. (1999). Manajemen Sumber Daya Manusia. Edisi Kedua. Yogyakarta: STIE YKPN.

Sugiyono. (2008). Metode Penelitian Bisnis (Pendekatan Kuantitatif, Kualitatif dan $R \& D)$. Bandung: Alfabeta.

Sugiyono. (2009). Metode Penelitian Bisnis (Pendekatan Kuantitatif, Kualitatif dan $R \& D)$ ). Bandung: Alfabeta. 